\title{
PRINCÍPIO DO PRAZER COMO REGULADOR DE UMA CIVILIZAÇÁO EM DECLÍNIO
}

\author{
Francisco Verardi Bocca ${ }^{1}$
}

\begin{abstract}
Resumo: Neste artigo, recusa-se o frequente pessimismo de Freud, tantas vezes denunciado por seus leitores, em relação à vida dos homens e aos destinos da humanidade, recusa auxiliada pela distinção, em sua obra, entre o domínio da metapsicologia e o da clínica. O primeiro domínio, fortemente associado à sistematização da psicanálise, admite um determinismo naturalista que, em seus termos, não prevê a autodeterminação do homem, da civilizaçáo e seus destinos, isto é, não tem a liberdade como uma noção operatória, caso em que as especulaçóes teóricas foram compostas por certo ponto de vista evolucionista, partilhado com a biologia, assim como pelo ponto de vista entrópico, partilhado com a física. Sustenta-se que a metapsicologia foi assim concebida na ordem dos princípios que orientam a evolução de cada homem e da humanidade, segundo uma finalidade que comporta sua própria exaustão, por isso é aqui denominada entrópico-declinista. O segundo domínio, relacionado ao diagnóstico e às técnicas de cura, comporta uma noção de homem e de civilizaçấo que, longe de ser resultado de uma providência natural ou sobrenatural, o é de si mesmo, caso em que admite um tipo de autoesclarecimento, de escolhas e mesmo de autorregulação visando, no limite, à autoprodução humana que permite postergar o destino entrópico da humanidade, que neste texto se nomeia de emancipatória. Da distinçáo metodológica de ambas, espera-se discernir a filosofia da história e da natureza que estaria contida em sua obra.
\end{abstract}

Palavras-Chave: Psicanálise. Clínica. Metapsicologia. Evolução. Entropia.

${ }_{1}$ Professor Titular do Programa de Mestrado e Doutorado em Filosofia da Pontifícia Universidade Católica do Paraná (PUCPR), Curitiba, PR - Brasil. ID https://orcid.org/0000-0001-6337-9263

E-mail: francisco.bocca@pucpr.br

Doutor em Filosofia pela Universidade Estadual de Campinas (Unicamp) (2001); Mestre em Filosofia pela Unicamp (1994); Bacharel e Licenciado em Filosofia pela Unicamp (1997); e Graduado em Arquitetura e Urbanismo pela PUCCAMP (1985). Pós-Doutor em Filosofia pela UFSCar (2009), e pela Universidade de Paris VII - Denis Diderot (2014). Atua nos seguintes temas: Filosofia da História, Psicanálise, Literatura e Ética. Integra e coordena a linha de pesquisa Filosofia da Psicanálise; compóe e lidera o grupo de pesquisa Filosofia da Psicanálise (PUCPR), cadastrado no CNPq. Compóe ainda os grupos de pesquisa Filosofia e Psicanálise (UFSCar) e Filosofia e Práticas Psicoterápicas (Unicamp), cadastrados no CNPq. No biênio de 2008 a 2009, ocupou a coordenação do GT Filosofia e Psicanálise da ANPOF. Membro associado da Associação Brasileira de Estudos do Século XVIII. Foi bolsista produtividade pela Fundação Araucária - PR, no ano de 2013. É coautor da obra Ontologia sem espelhos (Editora CRV, 2015) e autor da obra Do Estado à orgia (Editora CRV, 2016).

http://dx.doi.org/10.1590/0101-3173.2019.v42n1.07.p123

This is an open-access article distributed under the terms of the Creative Commons Attribution License. 


\section{INTRODUÇÃo}

Pretendemos, neste artigo, recusar o frequente pessimismo de Freud, tantas vezes destacado por seus leitores, em relação à vida dos homens e aos destinos da humanidade. Nós o faremos, distinguindo em sua obra o domínio da clínica e o da metapsicologia. Pelo primeiro domínio, podemos considerar que o homem e a civilização não seriam resultados de uma providência, mas de si mesmos, caso em que a história individual e da espécie decorreria de autoesclarecimento, uma concepçáo que admite escolhas, visando à autoprodução humana. Desde já o nomeamos emancipatório. Pelo segundo, podemos admitir um determinismo naturalista que impede a autodeterminação de si e da civilização e seus destinos, caso que pode ser compreendido pela presença de certo ponto de vista evolucionista da biologia, mesclado a um ponto de vista entrópico da física; nós o nomeamos de declinista. Esperamos, dessa distinção metodológica, revelar a filosofia da história e da natureza que, jamais pessimista, estaria contida na obra de Freud.

Pois bem, se qualificamos a clínica como emancipatória e, portanto, otimista, é porque ela, entre outras coisas, oferece as possibilidades terapêuticas que, em algumas oportunidades, Freud prometeu, como a habilitação e a capacitação do Eu para viver e ser feliz. Já a metapsicologia, mais precisamente seu ponto de vista de vista econômico, articula princípio do prazer e pulsáo de morte, o que redimensiona suas expectativas. A fim de mostrarmos o tipo de "jogo" que a clínica e a metapsicologia estabelecem, começamos por distinguir algumas de suas noçóes fundamentais. Sumariamente, diremos que, no primeiro caso, a agressividade e o mal-estar não seriam mais do que constataçóes de observaçóes clínicas. No segundo, acrescida de noçôes como instinto de morte, ${ }^{2}$ a volta ao inorgânico e ao declínio civilizatório outra coisa não se trata mais do que especulaçóes ${ }^{3}$ ambientadas no pensamento evolucionista da biologia e na termodinâmica da física. Desse modo, clínica e metapsicologia oportunizam uma coexistência, por exemplo, entre complexo de Édipo clinicamente observado e "especulaçóes convencionais" que pressupóem um destino finalista-declinista para a humanidade e para a vida na Terra. Tal justaposição foi também definida por Freud (1920, p. 69) como uma estratégia de "combinação" entre material concreto advindo da clínica e especulação teó-

\footnotetext{
${ }^{2}$ Adotaremos o termo instinto como opção de tradução de Trieb, em função da edição da Editora Imago das obras completas de Freud, utilizada nas citaçóes.

3 Sobre isso, consultar artigo de minha autoria, intitulado "Freud e o programa científico kantiano". Revista Natureza Humana, v. 18, n. 2, 2016.
} 
rica. É uma combinação que articula e, portanto, pôe em jogo o otimismo do esclarecimento e da autonomia do paciente e o finalismo-declinista das forças (instintuais) entrópicas que o habitam. Uma combinação aparentemente contraditória, a qual merece ser esclarecida.

Esse tipo de articulação, combinação ou justaposição metodológica pode ser ilustrado, por exemplo, nas consideraçôes acerca da agressividade humana. É verdade que Freud a observou na relação edipiana, mas também a especulou como subsistente na "natureza humana" ou, ainda, como característica universal de todo instinto. A agressividade, enquanto masoquismo primário, foi considerada, pelo próprio Freud (1920, p. 65), uma maneira de tratar as coisas que, como reconheceu, parece "mística".

\section{ENTRE A ABERTURA PARA O FUTURO E O DECLÍNIO INEXORÁVEL}

Nossa estratégia argumentativa consiste em considerar, de maneira intercalada, os dois pontos de vista mencionados acima: o emancipatório, relacionado ao esclarecimento que a análise proporciona, e o declinista, associado ao Princípio do prazer como regulador de uma civilização cuja finalidade seria o declínio da vida em geral, justificado no argumento, jamais recusado por Freud, do retorno ao inorgânico.

Levando isso em conta, reconhecemos que há em Freud uma possibilidade de resistência da vida e do progresso civilizatório da humanidade. Uma postergação indefinida do declínio para o qual pode contribuir a própria psicanálise, como frisado acima, pela via do esclarecimento que proporciona, da escolha e gestão dos destinos da vida instintiva humana, condição pela qual a humanidade passaria a dispor da possibilidade de interromper (pelo menos até certo limite) a produção de mal-estar ou, ao menos, resistir às suas consequências, estendendo sua existência na forma de um prolongamento aberto e contínuo. Nesses termos, a clínica consistiria num dispositivo que seguiria postergando ao infinito, de maneira assintótica, o alcance da meta da vida instintual humana.

Pois bem, comecemos por lembrar que, em pelo menos uma ocasiáo, nem a pecha de pessimista, nem de declinista, lhe cabem bem. Trata-se da obra O futuro de uma ilusão, de 1927. Nela, Freud (1927, p. 17) sustentou que "toda civilização tem de se erigir sobre a coerção e a renúncia ao instinto", referindo-se especialmente às suas tendências agressivas e antissociais 
facilmente reconhecíveis. Trata-se de um expediente a serviço dos elevados interesses civilizatórios. Nesse momento, fez-lhe sentido postular um tipo de civilização que, sendo resultado de tal renúncia, oferecesse aos homens alguma recompensa expressa na forma de progressos.

No entanto, nessa mesma obra, Freud (1927, p. 18) ressaltou que, relativamente aos homens, "os argumentos não têm valia alguma contra suas paixôes", admitindo a dificuldade em promover a coerção e a renúncia aos instintos. Contudo, alimentou a expectativa de que uma possibilidade de correção das imperfeiçóes dos regulamentos sociais, somada a uma educação que promovesse uma opiniáo elevada acerca da razão, poderia auxiliar na promoção do processo e do interesse civilizatório. Reunindo observação e especulação, Freud assim equacionou sua expectativa:

Provavelmente uma certa porcentagem da humanidade (devido a uma disposição patológica ou a um excesso de força instintual) permanecerá sempre associal; se, porém, fosse viável simplesmente reduzir a uma minoria a maioria que hoje é hostil à civilização, já muito teria sido realizado -talvez tudo o que pode ser realizado. (FREUD, 1927, p. 19).

Dito isto, passou a discutir o papel relevante da religião e da ciência, para essa conquista. Reconheceu que a primeira já teria prestado grandes serviços em favor da civilização, justamente no controle dos instintos. Contudo, o limite de sua contribuiçáo estaria no fato de que a religiáo, assim como toda forma de ilusão, apenas até certo ponto pode preparar o homem para a vida social esperada, porque, ao mesmo tempo, ela constitui obstáculo ao progresso da racionalidade, entre outras coisas, pelo distanciamento da realidade que lhe é característico.

Por sua vez, considerou que o novo espírito científico moderno abriu novas expectativas otimistas e positivas, pois teria confrontado o homem com temas específicos do mundo e da vida, enfraquecendo a representação religiosa e proporcionando o enfrentamento da realidade e de suas implicaçóes, fato que inaugurou a possibilidade concreta de superação do fardo da vida civilizada, incluindo a reconciliação do homem com ela. Até aqui, parece explícita sua adesão à possibilidade de uma civilização construída e sustentada em uma consciência esclarecida. Desse modo, sendo a religião "a neurose obsessiva universal da humanidade" (FREUD, 1927, p. 57), seu enfraquecimento permitiria, continuou, "a fatal inevitabilidade de um processo de crescimento" (FREUD, 1927, p. 57), isto é, de uma gestão racional de nossa vida instintual 
possibilitadora do progresso social, pois, como reconheceu Freud, "os homens não podem permanecer crianças para sempre, têm de, por fim, sair para a vida hostil." (FREUD, 1927, p. 64).

Nessa obra Freud acabou por expressar, com toda prudência, a expectativa em relação à possibilidade de a psicanálise poder oferecer muito mais que alívio ao sofrimento dos homens, na medida em que, uma vez esclarecidos, em lugar de vivenciarem suas ilusôes e fantasias, experienciariam a realidade na condição de sujeitos autônomos em relação às suas vidas. Assim, superadas as ilusóes religiosas, sempre supondo que o espírito científico moderno não teria construído outra e nem ocupado seu lugar, adviria uma ressignificação da vida, condição segundo a qual "a civilização não mais seria opressiva para ninguém." (FREUD, 1927, p. 64). Tudo porque, como definiu, "as transformaçóes da opinião científica são desenvolvimentos, progressos." (FREUD, 1927, p. 70). Nesse caso, seria um ganho de consciência que ofereceria a possibilidade de pôr em ação o motor do progresso e da autorrealização da civilização, uma verdadeira via aberta para o futuro e, quem sabe, para a perfectibilidade humana.

A via aberta ao futuro, que de certa forma superaria todo obstáculo à conservação da vida, teria sua justificativa no que Freud chamou de "novo espírito científico", pois já estaria ele mesmo a indicar o estágio elevado e promissor da história humana, porque o espírito científico já seria ele próprio resultado de um outro progresso, ocorrido no passado. Detalhes sobre essa ocorrência encontramos em uma certa filosofia da história que Freud já havia apresentado, em obra anterior, intitulada Totem e tabu, de 1913, particularmente no capítulo que recebeu o nome de Animismo, magia e onipotência de pensamentos. Nessa obra, conjugando Charles Darwin com Auguste Comte, expôs um certo evolucionismo especulativo acerca da evolução filogenética ${ }^{4} \mathrm{da}$

\footnotetext{
${ }^{4}$ Esse ponto de vista deriva de seu contato com a biologia evolucionista, possibilitado pela publicação, na cultura germânica, da tradução de H. G. Bronn da Origem das espécies de Darwin, amplamente divulgada por Haeckel, Weismann, Muller e Carl Claus, obra que introduziu a abordagem histórica na investigação da natureza. Quanto a Freud, lembramos que, antes de se ocupar da investigação do sistema nervoso da lampreia, no laboratório de fisiologia de Brücke, já havia se dedicado à pesquisa das gônadas das enguias, no laboratório de Claus. Ambas essas experiências antecederam, com igual perspectiva genética, sua investigação do sistema nervoso humano, no Instituto de Anatomia Cerebral de Meynert. Nesse percurso, visou à ontogênese das células sexuais, bem como ao decurso filogenético
} 
consciência humana, segundo diferentes e sucessivas formas de representação do universo. Conforme Freud (1913, p. 84), "a raça humana, se seguirmos as autoridades no assunto, desenvolveu no curso das eras, três desses sistemas de pensamento - três grandes representaçóes do universo: animista (ou mitológica), religiosa e científica”. Quanto às autoridades que referiu, mas não nomeou, supomos tratar-se, sem dúvida, de Comte e, especialmente, das teses de seu Curso de filosofia positiva, de $1842 .{ }^{5}$

Pois bem, Freud (1913, p. 84) definiu o primeiro sistema de pensamento como apto a "apreender todo o universo como uma unidade isolada de um ponto de vista único", admitindo ser a mais completa e verdadeira explicação da natureza do universo. Nesses termos, o animismo foi por ele considerado uma "doutrina de almas e, no mais amplo sentido, a doutrina de seres espirituais em geral." (FREUD, 1913, p. 82). No entanto, longe de representar um estágio superado, trata-se de uma primitiva filosofia da natureza que sobrevive entre nós, reconheceu Freud, inclusive entre aqueles que mantêm "uma crença muito limitada na existência de espíritos e explicam os fenômenos naturais pela influência de forças físicas impessoais.” (FREUD, 1913, p. 83).

Já relativizando a noção de progresso, admitiu, portanto divergindo de Comte, a coexistência das três formas de pensamento, mesmo entre os povos que se encontram atualmente dotados do espírito científico. Assim, estes não estariam demasiadamente longe do animismo, quando muitas vezes acreditam possuírem alma. Logo, Freud identificou a sobrevivência de traços primitivos da espécie, no desenvolvimento do indivíduo, vale dizer, a sobrevivência e a coexistência de modos de representaçôes pretéritas no estado contemporâneo, uma vez que, como observou, da primitiva representação "grande parte persiste na vida moderna, seja sob a forma degradada da superstição, seja como a base viva de nossa fala, nossas crenças e nossas filosofias." (FREUD, 1913, p. 84). Dessa maneira, conjugou o ponto de vista moderno acerca do progresso com uma particularidade, a perenidade e a coexistência de estados de consciência na própria evolução anímica do homem.

Perenidade e coexistência, contudo, não significavam estagnação, pois, lembrando Comte, compartilhou a possibilidade de superação da imaginação pela observação que a passagem do mito à ciência promoveu, sustentando a

do sistema nervoso nos seres vivos, inclusos os humanos. Trata-se do mesmo recurso teórico e metodológico de suas pesquisas sobre neurose, em cuja etiologia reconheceu a presença de estruturas arcaicas.

5 Sobre essa questão, consultar capítulo de minha autoria, intitulado "Comte com Freud - possibilidades de pensar a história”. In: Pluralismo na psicanálise. Curitiba: Editora PUCPRESS, 2016. p. 29-55. 
expectativa de esclarecimento e de consideração cada vez mais relevante da realidade, algo providencial para o progresso humano. Explicitou claramente as condições de superação da imaginação, sempre povoada e orientada por desejos, uma superação favorecida pela consideração progressiva das condições exteriores, ou seja, objetivas. Portanto, todo progresso material, social, moral, político, entre outros, que pressupõem a consideração da realidade, têm como condição a renúncia à realização de desejos, vale dizer, ao próprio narcisismo. No entanto, arrefecendo o tom otimista, ressaltou que, remanescente no funcionamento da mente primitiva, há também o mecanismo da projeção, bem como a ambivalência dos sentimentos, os quais são ainda hoje empregados da mesma maneira, num grande número de situaçóes que conduzem à neurose.

Nessa perspectivação histórica, quer dizer, filogenética, da humanidade, Freud levou adiante a identificaçáo do neurótico com o homem primitivo, promovendo, desde essa época, uma extensão entre sua psicologia individual (esta, sim, ontogenética) e de grupo, só mais tarde concluída, em 1921. Lembrou que "os tabus dos selvagens polinésios, afinal de contas, não se acham tão longe de nós como estivemos inclinados a pensar, a princípio" (FREUD, 1913 , p. 32), frisando também "que as proibições morais e as convençôes pelas quais nos regemos podem ter uma relação fundamental com esses tabus primitivos." (FREUD, 1913, p. 32). Evidentemente, resgatava argumentos de Atos obsessivos e práticas religiosas, de 1907. Com isso, lançou uma ponte entre a criança e o adulto, entre o último e o primeiro homem, valendo-se do ponto de vista evolucionista que articula a ontogênese explicada pela filogênese. Desse ponto de vista, reconheceu, como indicado acima, a sobrevivência do mecanismo de projeção, dos sentimentos ambivalentes e da onipotência de pensamento sempre presentes nos estágios sucessivos das diferentes formas de representação do mundo. Progresso admitido, apesar da sobrevivência de estágios anteriores e da "indestrutibilidade e insusceptibilidade à correção que constituem atributos do processo inconsciente.” (FREUD, 1913, p. 78). Condiçôes difíceis, mas ainda possibilitadoras do progresso civilizatório, que teria na psicanálise uma aliada.

De fato, a sobrevivência de traços do animismo e da religiáo, nos estágios posteriores, seria a maior resistência a ser ultrapassada pelo novo espírito científico e por sua ciência em construçáo, particularmente porque, como admitiu, o primeiro foi, de algum ponto de vista, o mais completo de todos. Ele não foi somente o primeiro e o mais completo, mas também, diz Assoun (1978, p. 98), "o modelo de todas as formaçóes culturais ulteriores (arte, reli- 
gião, filosofia), e não será totalmente eliminado, embora eficazmente neutralizado, na ciência”. O fato é que cada um dos três estados estaria, por assim dizer, construído um sobre os outros. Nesses termos, Freud sustentou um ponto de vista diverso do de Comte, pois, admitindo a variação lenta e gradual dos estágios, Freud se distanciou ainda mais de Comte e de suas divisóes abruptas e irredutíveis.

Em tempo, lembramos que a articulação entre ontogênese e filogêne$\mathrm{se}^{6}$ (presente no pensamento transformista da biologia, desde Lamarck) foi sustentada por Freud até seu leito de morte e inclusive retomada com todas as letras, em publicação tardia, como Moisés e o monoteísmo, de 1938. Não esqueçamos que, nessa obra, superando a dúvida, que admitiu em 1913, sobre a forma de transmissão dos processos e conteúdos psíquicos, Freud considerou-os sem interrupção herdados e convidou o leitor a supor "que ocorreu na vida da espécie humana algo semelhante ao que ocorre na vida dos indivíduos." (FREUD, 1938, p. 95). Assim, reforçou a tese da herança arcaica, isto é, da possibilidade de a vida psíquica de um indivíduo ser composta não somente do que experimentou, mas do que se faz inatamente presente e que tem origem filogenética.

Importante levar em conta que a hipótese filogenética teve como recurso adicional a possibilidade da herança do adquirido (tese cara, desde Lamarck), que ensejou a Freud a consideração do inconsciente como depositário de conteúdos arcaicos. Ela pareceu-lhe mais crível, pois, como psicólogo, concebeu ser mais fácil sustentar a tese de transmissão hereditária de traços psíquicos adquiridos, sujeita a menos objeção do que a de traços morfológicos. Assim, foi sob esse ponto de vista que atribuiu aos homens uma tendência a cumprir linhas de desenvolvimento psíquico.

Pois bem, foi justamente na obra de 1938 que Freud reconheceu que a biologia evolucionista, àquela altura, já havia dispensado a tese da recapitulação. A despeito disso, Freud justificou sua insistência na tese abandona$\mathrm{da}$, indicando, por exemplo, a presença do elemento cultural que chamou de simbolismo na linguagem e nos comportamentos humanos, como oriundo de

\footnotetext{
${ }^{6}$ Ritvo (1992) indica o forte interesse pela apresentação de Darwin para o público de língua alemã, por Haeckel, destacando que sua obra $A$ história da criação: o desenvolvimento da Terra e seus habitantes por causas naturais, estava em sua quarta edição, quando Freud ingressou na Faculdade de Medicina de Viena, onde tomou contato e assumiu distinção entre filogenia e ontogenia. Assinala Haeckel: "Esses dois ramos da história orgânica do desenvolvimento -ontogenia, ou a história do indivíduo, e filogenia, ou a história da tribo- mantém-se em estreita conexão causal, e um não pode ser compreendido sem o outro." (HAECKEL, 1876 [1868], 2: 348 apud RITVO, 1992, p. 31).
} 
uma ancestralidade. ${ }^{7} \mathrm{Na}$ verdade, era uma insistência que se justificava em sua conveniência para a ciência a qual se propunha dar os traços finais.

Com esse ânimo, Freud (1938, p. 114) confessou que não podia prescindir desse "fator da evolução biológica", justamente pelo fato de que, sem ele, estaria impedido de sustentar a perspectiva histórica, vale dizer, a ponte entre o passado e o presente, entre a psicologia de grupo e a do indivíduo, em última instância, de estabelecer a continuidade entre os fatos históricos, justificada, por exemplo, na herança do adquirido, na fixação e regressão a pontos pretéritos etc. São todas teses biológicas, que, se abandonadas, equivaleria a renunciar à sua ciência, à sua metapsicologia, com repercussóes na sua clínica (quem sabe, resultaria numa clínica da contingência?). Justificou ainda, declarando que a dificuldade de sustentação de tais teses, na biologia, não apresentava a mesma força em sua psicologia, uma vez que podemos reconhecer tais conteúdos nos traços de memória compostos por simbolismos, nos sonhos típicos, nas fantasias de conteúdo arcaico, nas expressões linguísticas, mitos, lendas e ritos.

Freud reafirmou, dessa forma, a oportunidade e a utilidade, para a psicanálise, de continuar sustentando (na verdade, especulando) que "os homens sempre souberam (dessa maneira especial) que um dia possuíram um pai primevo e o assassinaram" (FREUD, 1938, p. 115), que tiveram uma experiência ancestral herdada, transmitida e repetida (de algum modo, não completamente conhecida), sem descontinuidade. Foi por esse recurso conjectural que Freud manteve, em perspectiva evolucionista e continuísta, os fatos históricos, acedendo ao que é da ordem do originário e de sua evolução, explicando os primórdios (e a sobrevivência) da moralidade e das instituições humanas, na perspectiva de progressos e avanços culturais, mas também, digamos agora, como produtora de intolerância, de agressividade e de mal-estar.

\footnotetext{
${ }^{7}$ Lembramos que, desde o verbete Histeria, de 1888, Freud visou, na biografia do paciente, à investigação ontogenética de seu sintoma, que mais tarde associou, a partir de Estudos sobre histeria, de1895, ao seu passado filogenético objetivando assentá-la em um solo firme, distante da contingência. Já recusando a hereditariedade (de Charcot), investigou outros fatores etiológicos filogeneticamente fixados, tomados como patrimônio da humanidade, como fobias e comportamentos primários, os quais, de certa forma, remetem ao tema darwinista das expressôes das emoçôes, articulando o presente ao passado, a uma herança instintiva da humanidade. Trata-se de uma herança arcaica, que pode ser investigada no presente, pela análise do sintoma (além de comportamentos e hábitos linguísticos), assim como dela obter sua explicação pela análise dos mitos, por exemplo. Desse modo, pelo sintoma, acessa o passado e transcende o indivíduo em direção ao grupo, articulando pontos de vista físico, biológico e antropológico.
} 
Antes de nos determos nesse aspecto de seu pensamento, lembremos que, para ele, em todo processo histórico se dá, como disse, "modificações na estrutura das comunidades humanas" (FREUD, 1938, p. 97), modificaçóes que articulam fixação, variação, transmissão e coexistência do adquirido, as quais se deram por conta da superação da magia e da crença em ilusôes religiosas. Essa superação que teria ocorrido na forma de um "convite a avanços na intelectualidade (espiritualidade), e de seu incentivo às sublimaçóes." (FREUD, 1938, p. 100). Com esse argumento, pareceu esbanjar confiança na espontaneidade da razão. Entretanto, tomemos cuidado, porque, se, por um lado, nessa obra atribuiu ao movimento de ascensão espiritual que resultou no monoteísmo e representou um avanço em intelectualidade ${ }^{8}$, por outro lado, pensou tratar-se de um avanço que proporcionou resultados morais negativos e duradouros, os quais merecem ser avaliados com cautela, pois póem mais uma vez em questão a própria noçáo de progresso. ${ }^{9}$

Dizemos isso, apesar do fato de que o monoteísmo trouxe consigo uma concepção grandiosa de Deus, a ponto de deslocar para um segundo plano sua percepçáo sensorial, enquanto o apresentou como uma ideia abstrata. No entanto, observou Freud, foi um avanço ou mesmo uma sofisticação em intelectualidade, que tem sua contrapartida no retrocesso em sensibilidade. Mais do que isso, segundo ressaltou, "um triunfo da intelectualidade sobre a sensualidade, ou, estritamente falando, uma renúncia instintual, com todas as suas consequências psicológicas necessárias." (FREUD, 1938, p. 127). Na verdade, não se pode negar tratar-se de uma extraordinária evolução, que corresponde efetivamente a "um dos mais importantes estádios no caminho da hominização" (FREUD, 1938, p. 128), concluiu Freud, pois consistiu num passo momentoso em direção ao controle instintual e à valorização de sua renúncia, todavia, paradoxalmente, também do incremento da agressividade e do mal-estar, porque, do ponto de vista econômico, a renúncia instintual ou mesmo a postergação de sua satisfação conduzem a um aumento contínuo e acumu-

\footnotetext{
${ }^{8}$ Em favor desse ponto de vista, lembremos que, segundo Kant, o monoteísmo é resultado do percurso natural da racionalidade humana. Para ele, "em todos os povos vemos o seu mais cego politeísmo ser perpassado por algumas centelhas de monoteísmo, ao qual conduziu náo a reflexáo e profunda especulação, mas um caminho natural -tornado passo a passo compreensível- do entendimento humano." (KANT, 1781/1983, 618, p. 296).

9 Ecoando essa crítica, Loparic (2007, p. 70) adverte: "É interessante notar que Freud atribui o malestar na civilização não somente à moral religiosa -à religiâo enquanto ilusão-, mas também à razão iluminista. A sua teoria da censura neurotizante trabalha tanto com o conceito de repressáo não-esclarecida quanto com o de repressão esclarecida, uma vez que a objetificaçáo como tal, pode ser repressiva ao ser intrusiva ou impossibilitadora da vida humana."
} 
lativo de tensão, portanto, de produção de desprazer. Assim, mais uma vez aplicando o ponto de vista metapsicológico aos argumentos empíricos, Freud introduziu, novamente, necessidade e finalidade que entendemos declinista.

Pois bem, concebido como uma enlevação moral, o monoteísmo proporciona ao homem, diz Freud (1938, p. 131-132), “orgulha(r)-se da renúncia instintual, como se ela constituísse uma realização de valor", ou seja, uma renúncia instintual que provoca no homem o júbilo por tê-la realizado. Sua avaliação sobre esse progresso segue nuançada, na medida em que indica um efetivo avanço cultural, mas que teve como consequência "o aumento da autoestima do indivíduo, tornando-o orgulhoso, de maneira que se sente superior a outras pessoas que permaneceram sob o encantamento da sensualidade." (FREUD, 1938, p. 129). Tal orgulho, como reconheceu, corresponde a uma arrogância, a um "narcisismo aumentado pela consciência de uma dificuldade vencida.” (FREUD, 1938, p. 133).

Assinalou que o monoteísmo constitui um avanço, o resultado de um elevado nível espiritual e intelectual alcançado por uma abstração até então inexistente, a crença em um Deus universal e único, que, como disse, "afastase inteiramente da sexualidade e ao mesmo tempo eleva-se para o ideal da perfeição ética." (FREUD, 1938, p. 133). Essa ética, no entanto, trouxe consigo a exclusão de outras religióes e povos, como no judaísmo, pela noção de um povo eleito por um Deus que manifesta preferência, circunstância que Freud denunciou, a partir da reconstituição histórica do monoteísmo egípcio (de Amenófis IV), o qual, operando por consideraçóes de exclusividade e universalismo, constituiu um estágio de onde "nasceu inevitavelmente a intolerância, que anteriormente fora alheia ao mundo antigo e que por tão longo tempo permaneceu depois dele.” (FREUD, 1938, p. 33). Isso, mais uma vez, relativiza a noção de progresso social e ético. Ora, Freud (1038, p. 100) identificou a intolerância religiosa, e outras formas, como derivadas do próprio progresso da razão universalista, que traz consigo a pretensão de "domínio mundial".

Vale lembrar que Freud já havia tratado desse tema, em oportunidade anterior, como no capítulo V de Psicologia de grupo e análise do ego, de 1921. Os argumentos que nela apresentou merecem rememoração. Considerando a igreja católica como um grupo artificial que tem em Cristo seu líder, reconheceu que teria sido por meio dessa funçáo que ela teria suprimido a agressividade, entre seus membros. Contudo, também observou que a constituição do grupo, pelo mecanismo de identificação, se deu ao custo da emergência de 
um campo antagônico que inclui, além da agressividade e da intolerância, a crueldade. Sobre isso, salientou Freud (1921, p. 110):

Uma religião, mesmo que se chame a si mesma de religião do amor, tem de ser dura e inclemente para com aqueles que a ela náo pertencem. Fundamentalmente, na verdade, toda religião é, dessa mesma maneira, uma religiáo de amor para todos aqueles a quem abrange, ao passo que a crueldade e a intolerância para com os que não lhes pertencem, são naturais a todas as religiôes.

Dessa maneira, admitiu que toda forma de grupo jamais supera o mecanismo que nomeou narcisismo das pequenas diferenças (reapresentado em 1930). Na verdade, eles se valem dele, de sorte que, quanto mais fortes a identificação e o laço interno, quanto mais convicção e unidade de pensamento, maior a intolerância ao que não abrange, ao que lhe é externo. A história das religióes mostra que o externo se torna objeto de exclusão, manifestando uma imensa capacidade para o ensimesmamento do grupo, para a construção de uma estrutura social que sobrevive escoando sua agressividade em direção a outro grupo, considerado adversário. Essa observação revela que o próprio mecanismo de constituição e de coesão interna do grupo cria as condições e se sustenta no antagonismo externo. É verdade que, do ponto de vista econômico, à primeira vista, esse mecanismo funciona como dispositivo de sobrevivência, ao impedir o acúmulo de tensão em seu interior, na medida em que, como dizem os físicos, rebaixa sua taxa de entropia positiva. Entretanto, resta saber se sua permanência seria uma alternativa de sustentação indefinida de grupos, postergando seu declínio definitivamente.

A propósito, Freud declarou, em $O$ mal-estar na civilização, de 1929, que, quando "o apóstolo Paulo postulou o amor universal entre os homens como o fundamento de sua comunidade cristã, uma extrema intolerância por parte da cristandade para com os que permaneceram fora dela tornou-se uma consequência inevitável.” (FREUD, 1929, p. 71). Reforçou o argumento, lembrando que, por outro lado, para "os romanos, que não fundaram no amor sua vida comunal como Estado, a intolerância religiosa era algo estranho." (FREUD, 1929, p. 72). Adiante, acrescentou que "toda renúncia ao instinto torna-se agora uma fonte dinâmica de consciência, e cada nova renúncia aumenta a severidade e a intolerância dessa última." (FREUD, 1929, p. 90).

O fato é que Freud considerou o avanço em moralidade dependente do controle, consciente ou não, da sexualidade e da agressividade que a acom- 
panha, o que foi possível reduzindo a intensidade da agressividade, mediante deslocamentos. Na verdade, Freud sempre levou em conta as consequências positivas e negativas dessa possibilidade. Tentaremos compreender seu saldo, retrocedendo a uma obra que julgamos de suma importância para ilustrar a vinculação entre o ponto de vista econômico e dinâmico de sua metapsicologia e a entropia da física. Trata-se da obra Moral sexual civilizada e doença nervosa moderna, de 1908. Nela, mais uma vez, Freud frisou, citando vários fenômenos sociais, que a vida civilizada seria a verdadeira fonte de mal-estar e da agressividade entre os homens. Nela, externou novamente sua convicção acerca do antagonismo entre civilizaçáo e vida instintual.

A especificidade dessa obra consiste primeiramente nos aspectos sociológicos que introduziu e, com eles, a opinião de que o processo civilizatório pelo qual passa a humanidade coloca seus próprios objetivos em risco, ou seja, atenta contra si mesmo, ao se constituir. Ora, o sucesso visado é sempre confrontado com a iminência de seu fracasso, por exemplo, pela emergência da doença nervosa moderna, seu principal dano, mas não o único, porque o mecanismo que possibilita a produção de resultados culturais é o mesmo que os põe em risco. Refletindo sobre os efeitos desse paradoxo, logo chegou à conclusão de que o processo civilizatório alcançou extraordinárias realizações, em todos os setores. Contudo, só foram alcançadas e só podem ser conservadas, por meio de um grande esforço psíquico, de uma grande deformação psíquica: é um progresso atingido segundo uma dialética negativa que comporta uma enfermidade, podemos dizer agora, que emerge de seu próprio interior, sem o qual talvez o homem se mantivesse psiquicamente saudável.

Freud denunciou o modo de vida caótico de nossas sociedades e concluiu pelas consequências que sofremos: "Tudo é pressa e agitação [...] os nervos exaustos buscam refúgio em prazeres intensos, caindo em ainda maior exaustáo" (FREUD, 1908a, p. 170-1), da qual há pouca oportunidade o homem civilizado tem de se recuperar. Identificou também um tipo de sintoma nervoso motivado pelo modo de vida da civilização moderna, mas acrescentou e destacou a presença de uma repressão instintual talvez excessiva, embora necessária, da vida sexual dos povos. Concluiu que, ao empreender esforços para suprimir a atividade sexual do homem, já que se nutre da energia que dela retira, a moral civilizada moderna atenta contra seus objetivos declarados e expõe sua contradição interna, consequência que busca remediar, apelando para a oferta de satisfaçóes substitutivas crescentes. 
Ele também descreveu o paradoxo em questão por uma analogia com os sistemas físicos. Ao assim proceder, como entendemos, produziu uma mudança de patamar nas consideraçôes acerca da natureza e das consequências de tal contradição - da condição de contingente, com possibilidades de autorregularão, para a condição fatalista e declinista. Vejamos. Essa mudança de patamar se deu, ao fazer referência a um tipo de conversão instintual operado pelo aparelho psíquico e estimulado pela civilização, ao qual chamou de sublimaçáo. Um dos destinos da vida instintual humana, na maioria das vezes, foi pensada como provedora de valor positivo para a civilização. Contudo, não dessa vez.

Como sabemos, a sublimação foi concebida como alternativa privilegiada da vida passional humana, particularmente quando sugere algo da ordem de um sistema homeostático, para nos mantermos no campo das metáforas das ciências naturais. Porém, especialmente nessa obra, Freud reconheceu a eficiência, mas também os limites de sua aplicação, problematizando seu estatuto de produtora de cultura. Nesse caso, prognosticou a degeneraçáo da civilização, sob a forma de uma doença nervosa progressiva, especulando sobre seu destino em bases entrópicas, ao negar à sublimação a condição de processo de reciclagem constante e eficaz, digamos, da vida instintual, o que permitiria evitar seu desgaste e exaustão, mantendo-a provida de sua quantidade e acrescida de qualidade, quer dizer, de cultura.

Ao considerá-la do ponto de vista entrópico, Freud retirou-a da condição de instrumento de reconciliação entre o Princípio do prazer e o Princípio de realidade (1908b e 1911), para submetê-la à regência do primeiro. De fato, Freud entendeu que todas as formas de transformação da vida instintual, inclusive a sublimação, comportam a meta de sua negação, de sua exaustão. Externou esse ponto de vista, ao declarar que toda operação do aparelho psíquico (inclusive a sublimação) procede em relação à energia instintual, "da mesma forma que em nossas máquinas não é possível transformar todo o calor em energia mecânica." (FREUD, 1908a, p. 174).

Com esse argumento, muitas vezes negligenciado por seus leitores, indicou que, do ponto de vista econômico, da sublimaçáo resulta, como nos artefatos mecânicos e na própria natureza física, uma perda necessária e inevitável de sua quantidade, quer dizer, produz o efeito de dissipação de energia em um mecanismo não reversível. Náo se pode negar que, ao reproduzir, quase que literalmente, o ponto de vista presente no princípio (ou ciclo) de Carno- 
t-Clausius, ${ }^{10}$ Freud revelou a face mais crua de sua filosofia da natureza, distante da homeostase como princípio regulador, inclusive do psiquismo. Como dissemos acima, ele o fez, articulando o ponto de vista biológico evolucionista a um ponto de vista físico entrópico, atribuindo indistintamente à natureza, ao homem e à civilização uma evolução, cuja finalidade seria a exaustão e o declínio. Ele o fez, assumindo e descrevendo um modo sempre em continuidade de evoluir da natureza física para a biológica e, desta, de volta para a física, ou seja, do inorgânico ao orgânico e deste, de novo, ao inorgânico. ${ }^{11}$ Tal ponto de vista imputa à ordem biológica, assim como à civilização, a "determinação" de completar a tarefa imposta pelo Princípio do prazer: conduzir o processo de evolução da vida humana rumo ao inorgânico.

Como visto, Freud concebeu a sublimaçáo como um mecanismo que opera ao modo entrópico, ou pelo menos sujeita ao mesmo princípio. A analogia entre os sistemas físicos e os humanos se deu pela consideração evolucionista de que nem mesmo a emergência da ordem biológica seguida da ordem social constituiu uma oportunidade de recusa ou de emancipação dos princípios da física ${ }^{12}$. Foi nesses termos que Freud anunciou a contradição interna que anima a relação dos homens regidos pela moral sexual civilizada:

Devo insistir em meu ponto de vista de que as neuroses, quaisquer que sejam sua extensão e sua vítima, sempre conseguem frustrar os objetivos da civilização, efetuando assim a obra das forças mentais suprimidas que são hostis à civilização. Desta forma, se uma sociedade paga pela obediência a suas normas severas com um incremento de doenças nervosas, essa sociedade não pode vangloriar-se de ter obtido lucros à custa de sacrifícios; e nem ao menos pode falar em lucros. (FREUD, 1908a, p. 186).

\footnotetext{
${ }^{10}$ Rudolf Clausius (1822-1888), físico e matemático alemão, foi um dos fundadores da termodinâmica, ao reafirmar o princípio de Nicolas Carnot (1796-1832). Em Sobre a teoria mecânica do calor, de 1850 , expôs pela primeira vez as bases da segunda lei da termodinâmica e introduziu, em 1865, o conceito de entropia.

${ }^{11}$ Fulgêncio salienta que a continuidade admitida (ao menos no nível da teoria e da ficção metapsicológica) ocorre "por analogia aos sistemas físicos, (admitindo) que o ser humano funciona tal qual um sistema termodinâmico, que procura eliminar as tensóes ou as diferenças de potenciais no seu interior." (FULGÊNCIO, 2008, p. 284). Para ele, este seria o sentido da hipótese de Freud de que o Princípio do prazer realiza a funçấo análoga àquela postulada pelo princípio inercial dos processos físicos e cerebrais: eliminar os estímulos que atingem o aparelho psíquico.

${ }^{12}$ Como disse André Lwof, em defesa da universalidade da entropia, "le système vivant considéré à une échelle universelle ne peut contredire le deuxième principe (de la thermodynamique)" (LWOFF, 1969, p. 173), mesmo que o fenômeno da reproduçâo produza uma entropia negativa e forneça uma ordem funcional aos organismos vivos, porque a sustentação da reprodução da ordem biológica depende do mesmo processo, "le métabolisme, qui est corrélatif d’un accroissement d’entropie." (LWOFF, 1969, p. 175), segundo concluiu.
} 
Como sabemos, ele retomou esse ponto de vista, em $O$ mal-estar na civilização, justamente onde avançou na análise do processo civilizatório, responsabilizando-o como produtor de toda ordem reconhecível de mazelas, como mal-estar e neuroses, mas com o acréscimo de que ele cria obstáculos ao cumprimento imediato da meta de satisfação da vida instintual.

De acordo com sua visão, o mal-estar crescente e as doenças nervosas podem ser explicados como resultantes da adaptação à realidade, já que implicam submissão a ela. Dessa feita, a fonte consiste no obstáculo que a realidade impóe à meta do escoamento imediato das excitaçôes sofridas pelo aparelho psíquico, ao pronto funcionamento do seu mecanismo de arco-reflexo, funcionamento regido pelo Princípio do prazer obstaculizado pelo Princípio de realidade, que agrava o conflito, ao estimular a criação de formas protetoras. Segundo entendemos, Freud concebeu os homens coexistindo segundo uma dinâmica que apenas posterga seu desfecho, mas sem abdicar da sua finalidade. Mais ainda, o próprio modus operandi do Princípio de realidade cria contrariedades crescentes e fortalece a regência do Princípio do prazer, impulsionando o cumprimento de sua meta, conforme destacou Freud (1920, p. 20):

Esse último princípio não abandona a intenção de fundamentalmente obter prazer; não obstante, exige e efetua o adiamento da satisfação, o abandono de uma série de possibilidades de obtê-la, e a tolerância temporária do desprazer como uma etapa do longo e indireto caminho para o prazer. Contudo, o princípio de prazer persiste por longo tempo como o método de funcionamento empregado pelos instintos sexuais, que são difíceis de "educar", e, partindo destes instintos, ou do próprio ego, com frequência consegue vencer o princípio de realidade, em detrimento do organismo como um todo.

Foi nessa condição que Freud identificou um mal-estar crescente na civilizaçáo, ora atribuindo-o ao modo de vida, ora ao funcionamento do aparelho psíquico, ora a ambos. A meta anunciada indica a ineficácia do Princípio de realidade somada à resiliência do Princípio do prazer. Baseado nisso, Freud admitiu um conflito de interesses entre a reivindicação dos indivíduos, que seria de escoamento de excitaçóes, e a reivindicação da civilização, que seria de sua conservação, condição que reforça enormemente toda dúvida sobre o destino da humanidade e que sustenta toda incerteza de saber se "tal acomodação pode ser alcançada por meio de uma forma específica de civilização ou se esse conflito é (seria) irreconciliável.” (FREUD, 1929, p. 50). Na verdade, Freud quase nunca se mostrou otimista, em relação ao sucesso dessa equação. Com 
efeito, com ânimo "pessimista", acrescentou que "não é fácil entender como pode ser possível privar de satisfação um instinto. Isso não se faz impunemente." (FREUD, 1929, p. 52).

Avançando nessa direção, reapresentou a tese de que os homens seriam criaturas entre cujos dotes instintivos se deve levar em conta uma imensa e sempre presente cota de agressividade, inclusive contra si mesmos, sob forma de autodestrutividade. Esta foi definida como masoquismo primário, a partir de 1924, em O problema econômico do masoquismo. Assim concebida, tal agressividade primária e subsistente nos homens colocaria a civilização em uma marcha constante de desintegração. Nessa condição, fica justificada a necessidade, mesmo que inócua, de formaçóes reativas que lhe oponham resistência, mas nunca sua anulaçáo, particularmente porque, paradoxalmente, a supressão de sua agressividade não seria razoável, uma vez que, reconheceu Freud, "sem ela, eles (os homens) não se sentem confortáveis." (FREUD, 1929, p. 71). Nesses termos, ela foi compreendida num duplo registro, a saber, tanto quanto expressão clínica de relaçóes humanas quanto uma disposição instintual, como instinto de morte. Em ambos os casos, como resistência e entrave aos supostos propósitos adaptativos da civilização. Freud enfatizou que "a inclinação para a agressão constitui no homem, uma disposição instintiva original e auto subsistente [...] ela é o maior impedimento à civilização" (FREUD, 1929, p. 81).

Ele também assumiu, nessa obra, a incumbência de revelar os modos pelos quais a civilização lida reativamente com a agressividade de seus membros, visando a aquiescê-la, a torná-la inócua. Tal iniciativa adviria do que chamou Supereu, provocando a introjeção da agressividade, como disse, "enviada de volta para o lugar de onde proveio" (FREUD, 1929, p. 83), ou seja, ao Eu. Reconheceu que essa operação promove uma absorção da agressividade, não pelo Eu todo, antes por parte dele, que a exerce contra o restante do aparelho. Longe de constituir uma solução reconciliadora, essa operação potencializa uma tensão permanente entre as instâncias psíquicas, a qual resulta, inclusive pelo sentimento de culpa, na necessidade de autopunição (cuja extensão foi exemplarmente mencionada, entre outras obras, em Criminosos em consequência de um sentimento de culpa, de 1916).

No entanto, foi dessa forma que Freud concebeu que "a civilização, portanto, consegue dominar o perigoso desejo de agressão do indivíduo, enfraquecendo-o, desarmando-o e estabelecendo no seu interior um agente para cuidar dele, como uma guarnição numa cidade conquistada" (FREUD, 1929, p. 84), sempre deixando claro que as instituiçóes civilizadoras potencializam 
o ressentimento dos indivíduos, reconfigurando sua agressividade, em lugar de suprimi-la. Nos termos colocados, a agressividade é de fato agravada, justamente ao ser impedida de alcançar sua meta de satisfação.

Uma vez apresentados os argumentos que anunciam os obstáculos, e até mesmo as impossibilidades, à harmonização dos interesses em jogo, avançaremos, acrescentando um agravante. Trata-se da possibilidade de um funcionamento regressivo do aparelho psíquico (de inspiração lamarckista). De fato, pretendemos abordá-lo como possibilidade de regressão, mas também de involução (de inspiração darwinista) estendida aos estágios civilizatórios. Para isso, recorreremos a um pequeno texto de Freud, intitulado Reflexóes para os tempos de guerra e morte, de 1915. Segundo entendemos, essa é uma obra que repercute de maneira exemplar a perspectiva declinista de sua metapsicologia.

Redigida no calor da Primeira Guerra Mundial, foi organizada em duas partes, as quais receberam os títulos $A$ desilusão da guerra e Nossa atitude para com a morte, ambas relativas a duas questóes que afligem a humanidade, especialmente em períodos de guerra. A primeira aponta para o fato de que, de todos os prejuízos materiais que a guerra pode causar, nada se compara à desilusão, por conta do declínio ético que acarreta. Sua reflexão sobre a guerra começou por relatar uma série de frustraçóes e pessimismos, um imenso desapontamento em função das atrocidades perpetradas pelos países beligerantes, desapontamento agravado pela expectativa que o cidadão europeu se habituou a alimentar, quanto ao estágio alcançado e ao papel civilizatório das grandes naçôes. Delas esperavam, disse Freud (1915, p. 286), que "conseguissem descobrir outra maneira de solucionar incompreensóes e conflitos de interesse." Frustração sobretudo pela guerra ocorrer entre naçóes já submetidas a elevadas normas de conduta moral e inclusive lembrando, como signo de sua eticidade, o livre deslocamento e intercâmbio de pessoas que, como hoje, já ocorria à época, no continente europeu.

$\mathrm{Na}$ verdade, a beligerância acabou por evidenciar, em lugar da superação, a latência do conflito instintual. Em vez da tolerância, as nações perpetraram preconceito e crueldade. Em lugar do cosmopolitismo, nacionalismo exacerbado. $\mathrm{Na}$ realidade, Freud lamentou a perda da oportunidade de consolidação de sociedades plurais e tolerantes, da perda da oportunidade de substituição da noção de estrangeiro (ou inimigo) pela de hospitalidade. $\mathrm{O}$ agravante se deu ainda pela circunstância de que, caso um conflito fosse inevitável, seria conduzido sob normas civilizadas. 
Nessa reflexão Freud mostrou que, na verdade, o desapontamento seria decorrente de uma ilusão destruída, uma ilusão laboriosamente construída na modernidade e que encontrou, nos episódios da guerra, um confronto com a realidade. Do ocorrido, despertou para o fato de que, "na realidade, nossos concidadãos não decaíram tanto quanto temíamos porque nunca subiram tanto quanto acreditávamos", disse Freud (1915, p. 294). Admitiu que todo desenvolvimento moral, apenas aparentemente alcançado, está sempre fadado ao desmonte, justamente por ter sido resultado da tentativa malfadada de erradicação das disposiçóes humanas antissociais. A guerra colocou cada europeu diante do inevitável reconhecimento da "perpétua presteza dos instintos inibidos em irromper, em qualquer oportunidade adequada, em proveito da satisfação." (FREUD, 1915, p. 293). Nesse sentido, todo convívio social estaria sempre no limite de uma regressão à conformidade com a natureza instintiva do homem. Vemos, nessa reflexão, mais uma aplicação, por analogia, da possibilidade de que a civilização daria continuidade, por caminhos próprios, aos propósitos entrópicos dos sistemas físicos termodinâmicos.

No entanto, em nome de um certo otimismo, Freud não recusou o fato de que "cada nova geraçáo prepara o caminho para uma transformação de maior alcance do instinto, a qual será veículo de uma civilização melhor." (FREUD, 1915, p. 294). Dessa forma, deixou em aberto uma esperança, mais do que uma possibilidade, de conservação da vida e sustentação civilizatória, uma esperança de esquiva do destino entrópico do mundo físico, otimismo logo relativizado, quando apontou pela primeira vez para a possibilidade real de que todas as conquistas psíquicas e morais possam ser suprimidas. Na verdade, acabou por reconhecer que, enquanto resultado de um aparelho psíquico que funciona ao modo das máquinas termodinâmicas, todo processo civilizatório "pode ser descrito como (dotado de) uma capacidade especial para a involução.” (FREUD, 1915, p. 295). ${ }^{13}$

O destaque dado por Freud ao aspecto involutivo da natureza, assim como da civilização, merece atenção, principalmente porque dá sustentação ao caráter conservador que atribuiu ao instinto. Ele evidencia o primado do Princípio do prazer e de sua relação com o instinto de morte. Como nos ensinou Monzani (2014), ele permite refletir sobre o estatuto do prazer, na obra de Freud. Começamos por lembrar que a força instintual que é pelo Princípio

\footnotetext{
${ }^{13}$ Expressão que utilizou, em 1920 (p. 52), quando sustentou a tese da biologia de que um desenvolvimento é frequentemente acompanhado ou sobrepujado pela involução em outros aspectos, recusando mais uma vez a existência de instintos que visem à perfeição. Também em 1929 (p. 61), indicou que a vida sexual do homem moderno causa a impressão de passar por um processo de involução, enquanto função.
} 
do prazer orientada, mesmo quando se manifesta pela repetição, o faz para restabelecer um estado originário. Portanto, não se trataria de um simples fenômeno de repetição aberta sem finalidade, muito menos um simples repetir monótono. Nesses termos, é lícito dizer que restabelece um estado original, “já dado de antemão e que serve como finalidade (interna) da atividade repetitiva”, conclui Monzani (2014, p. 179).

Concebida com base no ponto de vista clínico, além de metapsicológico, a repetição, em tese, decorre do fato de que uma representação emerge no psíquico como representante de uma força instintiva livre, náo ligada, que por isso pressiona no sentido da descarga, por meio de um objeto que lhe sirva de alvo. Para atender a essa meta, na impossibilidade de uma maneira direta, requer uma mobilização do psiquismo para bloqueá-la, fixá-la, ligá-la. Trata-se de um trabalho de ligação, o qual, de início, parece contradizer o Princípio do prazer, já que vincula excitaçóes livres, em vez de escoá-las imediatamente. Seria o caso em que a repetição ocorreria apenas como tentativa de oportunizar a ligação, evitando sua descarga completa. Concebida dessa forma, torna-se legítimo perguntar, como fez Freud (1920), se a repetição não seria mais primitiva e independente do Princípio do prazer.

Especulações à parte, a repetição foi um fenômeno clinicamente identificado por meio das neuroses traumáticas frequentes no pós-guerra, dos sonhos igualmente traumáticos que trazem o paciente de volta à situação do acidente, por fim, por meio das brincadeiras de crianças. O fato é que a repetição foi especialmente reconhecida como característica do funcionamento do aparelho psíquico, a qual, por motivos econômicos, está relacionada à produção de prazer.

Pois bem, embora Freud também a tenha tratado como uma compulsão derivada da natureza mais íntima dos instintos e que, assim, seria suficientemente forte para desprezar o Princípio do prazer, ele o fez sem revogar a regência do Princípio do prazer, o desvencilhar-se de excitaçóes e, assim, obter prazer. Com Freud, consideramos que a repetição e a ligação de excitaçóes que ela proporciona constitui, na verdade, um ato preparatório, um ato preliminar, criador de condiçóes para seu escoamento, quer dizer, para submeter-se ao Princípio do prazer. Pensado dessa maneira, também ela visa à descarga de excitaçóes, seu verdadeiro propósito. Mesmo quando causa desprazer ao Eu, "não contradiz o princípio de prazer: desprazer para um dos sistemas e, simultaneamente, satisfação para outro” (FREUD, 1920, p. 31), ponderou Freud. Tal argumento, em síntese, define o modo de existência 
fundamental da força instintiva e o modo de funcionamento do aparelho psíquico, pela repetiçáo e ligaçáo como almejando um estado originário, alcançável através de sua extinção.

Trata-se de uma tendência que Freud, em sua especulação metapsicológica, considerou como um atributo da vida orgânica em geral, uma verdadeira expressão da inércia dos organismos que visa ao estado inorgânico mineral, perturbado em algum momento ainda insuficientemente conhecido. Apoiado nisso, pode-se dizer que toda ordem biológica e cultural estaria sujeita a esse movimento em direçáo ao estado anterior, por meio de uma descarga total da excitabilidade recebida. Todavia, nossas intuiçóes carecem ainda de evidências. Examinemos duas possibilidades.

O Principio do prazer, se tomado como o orientador do escoamento do excesso (seu acúmulo) de excitação, funcionaria de fato como princípio regulador dos processos psíquicos, à maneira anunciada por Freud, no capítulo VII de Interpretação dos sonhos, de 1900. É o caso em que ele recebeu identificação com o Princípio de constância, o qual expressa a tendência do aparelho psíquico de se conservar homeostaticamente. Nesse caso, estamos diante de uma perspectiva positiva do prazer. No entanto, as coisas nem sempre se passaram assim. Por exemplo, no primeiro capítulo de Além do princípio do prazer, já bem longe da influência de Breuer, a noção de prazer e de seu princípio ordenador ganhou novo estatuto. Nessa obra, ele perdeu a condição de guardião, digamos, da saúde psíquica, de responsável pela sustentação de um nível ótimo de tensão. Ao contrário, ganhou a condição de serviçal das forças instintivas, sobretudo as de morte. Seria correto dizer que Freud, nessa ocasião, teria assumido uma posição contraditória? Talvez não.

A resposta é não, se considerarmos que, em 1920, o Princípio do prazer apenas recuperou seu estatuto pretérito, ou seja, o de manter o aparelho livre de excitaçóes, à maneira do arco-reflexo, um aparelho que remove a excitação, libertando-se de sua presença. Em poucas palavras, nessa obra, Freud retirou o Princípio do prazer da subordinação ao Princípio de constância. Como indica Monzani, nesse momento, Freud de fato expôs o caráter paradoxal do prazer, pois trouxe a questáo de saber: ele seria "guarda costas da vida ou lacaio da morte?” (MONZANI, 2014, p. 191). Evidentemente, não se trata de uma questão simples, uma vez que tanto a funçáo de promover a ausência total de excitação, como a sua manutenção em nível constante, coexistiram na obra de Freud, de forma, digamos, embaralhada. Para esclarecê-la, Monzani recorreu ao Projeto de uma psicologia cientifica, de 1895 , onde a questão estava presente, 
em favor da noção de lacaio da morte, porque, nele, Freud levou em conta a inércia como princípio (diferente de lei da inércia ${ }^{14}$ ). Vejamos em detalhes.

Monzani salienta que os leitores atentos de Freud sabem muito bem sobre a vinculação do prazer com a inércia, que a obra de 1895 promoveu. Sabem também que os estímulos endógenos provocam, nessa tendência (à inércia), uma modificaçáo em termos de tolerância de uma quantidade mínima, o que faz da inércia, enquanto repouso, algo apenas da ordem do ideal. Admitida, nessa perspectiva, a constância não adviria como negação do repouso, como adverte Monzani, mas como sua solução, em vista da vinculação da excitação livre que recebe ligação no aparelho psíquico. Contudo, o que justificaria, no Projeto, pergunta Monzani, a inclusão de noçôes como repetição e ligação? A resposta é evidente: suprimir a condição livre de toda excitação, aquiescê-la, como condição de promover a evitação do desprazer. Vincular, a fim de que delas possa então se desvencilhar.

Seus leitores sabem igualmente que o responsável por promover vinculações de excitaçôes livres é o Eu. Este, enquanto organização, tem a função de promover inibição do escoamento, instaurando processos sofisticados, os quais, mesmo assim, visam à descarga, só que de forma adequada em relação à realidade interna do corpo. Em outros termos, ele tem a função de, ao fazer vinculaçáo, inibir o Processo primário, enquanto instaura o Processo secundário. Desse modo, resta razoável sustentar que, por caminhos alternativos, sua função permanece a da regulação inercial, vale dizer, impulsionar a tendência à morte. ${ }^{15} \mathrm{Na}$ verdade, um ponto de vista que implica considerar a

\footnotetext{
${ }^{14}$ Gabbi Junior esclarece que a lei da inércia não representa uma tendência ao repouso. Por sua vez, distinto dela, o Princípio da inércia, como concebido por Freud, além de expressar a ausência de aceleraçôes, expressa também a ausência de movimento. Para ele, o Princípio de inércia "exprime um caso em que a partícula material mantém o seu estado de movimento, cujo estado é o repouso" (GABBI JUNIOR, 2003, nota 7, p. 27), ou, como havia dito em edição anterior da mesma obra, "o princípio da inércia exprime um caso particular da lei da inércia, aquele onde a diferença entre movimento e repouso é nula" (GABBI JUNIOR, 1995, nota 7, p. 112). Assim, "em suma, o princípio da inércia expressa a tendência do sistema nervoso de evitar que ajam sobre ele forças que o obrigariam a abandonar seu estado de repouso." (GABBI JUNIOR, 2003, nota 10, p. 28). Entretanto, apesar de reconhecer a distinçâo entre lei da inércia e Princípio de inércia, Gabbi Junior recusa a tese (que atribui a vários comentadores) de que o Projeto já continha a noçáo de instinto de morte, porque a morte foi concebida nessa obra como algo externo à vida "e não como algo interno e condutor da vida, como será em 1920" (GABBI JUNIOR, 2003, nota 26, p. 34), arrematou.

${ }^{15}$ É verdade que, em 1924, em O problema econômico do masoquismo, em razão do difícil problema clínico do masoquismo, o qual associa prazer com sofrimento, Freud desvinculou novamente o Princípio do prazer da tendência inercial, identificando-o à constância, o que expõe ainda mais o caráter nuançado de suas construçóes teóricas.
} 
constância apenas como uma concessão momentânea, nunca a deposição da inércia. Voltando a 1920, podemos dizer agora que a velha tendência inercial foi, nessa ocasião, reapresentada de forma explícita, confirmando o estatuto do Principio do prazer.

Em todos esses argumentos, é possível perceber que a metapsicologia de Freud ocupou um lugar de operadora da clínica, da cultura, da arte, da religião, da história e da natureza. Logo, é imperativo reconhecer que, em relação a todos esses domínios, sem pressupor descontinuidade, ela projeta um devir evolucionista-entrópico. Sua metapsicologia, à maneira schopenhaueriana, observa que a racionalidade humana, longe de constituir uma força independente da vida instintiva, comporta-se como um instrumento dela. Nesses termos, Freud endossou a hipótese de que os caminhos da civilizaçáo seriam indicados pelas forças instintuais, em sua motivação fundamental, o prazer na quietude, o que possibilitou justificar fatos como a guerra, reconhecer nela razôes para satisfazer motivaçóes que nada mais seriam do que o cumprimento de interesses primitivos das forças instintuais, de sorte a admitir que a civilização emerge, não para se opor ou constituir alternativa ao seu destino entrópico, porém, para completar sua tarefa, finalizar o processo de evolução (conservadora) da vida rumo ao inorgânico.

Dessa forma, embora não seja consenso entre seus leitores, identificamos na obra de Freud, por toda parte, uma espécie de teleologia rigorosa que nunca abandonou e que pode ser ilustrada por um fio condutor que leva (arriscamos dizer que inexoravelmente e não apenas tendencialmente) do inorgânico ao inorgânico, a saber, que realiza o esforço mais fundamental da substância viva, que é o de retornar à quiescência do mundo inorgânico. Em suas próprias palavras, "o princípio de prazer, então, é uma tendência que opera a serviço de uma função, cuja missão é liberar inteiramente o aparelho mental de excitaçôes, conservar a quantidade de excitaçóes constante nele, ou mantê-la tão baixa quanto possível" (FREUD, 1920, p. 73), o que consiste em apoiar sua meta, a "fundamental de toda substância viva: o retorno à quiescência do mundo inorgânico.” (FREUD, 1920, p. 73).

Trata-se de um argumento fartamente presente, em Além do princípio do prazer, e que confirma a tese de que a vida civilizada não teria mais do que o encargo de atender, com todo recurso disponível, à máxima do Princípio do prazer, que, segundo Freud (1920, P. 74), "parece, na realidade, servir aos instintos de morte." Conforme indica Monzani (2014), atendendo a uma finalidade basicamente mortuária, argumento que parece dirimir dúvidas sobre 
a presença de um evolucionismo-entrópico ou de um finalismo-declinista em Freud, especialmente derivado de sua metapsicologia, do ponto de vista econômico e da teoria das forças que a compóem. Já a clínica, enquanto contraponto, não se prestaria a outra coisa senão a dar contornos ao intervalo entre a fonte e a meta da vida.

Todavia, resta refletir, a título de conclusão, sobre o uso analógico efetuado por Freud, isto é, sobre a atribuição de validade da segunda lei da termodinâmica para além dos sistemas físicos inertes. Nós o faremos, de início, retomando a obra de 1920, já que pode ser considerada a que comporta as concepçóes mais maduras de sua metapsicologia. O fato é que o instinto em geral foi definido como reativo ao mundo externo, o qual provoca a matéria inerte. Trata-se de sua relação de um organismo com o exterior, como disse Freud (1920, p. 48), "da história da Terra em que vivemos e de suas relaçóes com o Sol." Nesses termos, o instinto de morte teria se originado "da animação da matéria inanimada e procura $(\mathrm{m})$ restaurar o estado inanimado" (FREUD, 1920, p. 55), continuou. É um argumento em harmonia com a hipótese igualmente especulativa de que "o objetivo da vida não poderia ser o de alcançar um estado de coisas que jamais tivesse sido atingido." (FREUD, 1920, p. 49). Este só pode ser um estado pretérito já alcançado, de modo que seu conservadorismo só pode consistir em sua característica universal. Dessa forma, contrapôs-se à tese de Weismann (FREUDE, 1920, p. 57) de que a morte seria uma aquisição tardia da vida, além da recusa da possibilidade de instintos de perfeição e progresso.

A especulação de Freud se ocupou em definir a vida orgânica em geral. Disse ele:

Parece, então que um instinto é um impulso, inerente à vida orgânica, a restaurar um estado anterior de coisas, impulso que a entidade viva foi obrigada a abandonar sob a pressão de forças perturbadoras externas, ou seja, é uma espécie de elasticidade orgânica, ou, para dizê-lo de outro modo, a expressão da inércia inerente à vida orgânica. (FREUD, 1920, p. 47). 
Tal inércia é empregada no sentido de que "a entidade viva elementar, desde seu início, não teria desejo de mudar" (FREUD, 1920, p. 48), conforme completou, o que indica a natureza conservadora da substância viva expressa na tendência ao repouso, que se instala imediatamente após a emergência da vida. O próprio Freud questionou se, ao lado dessa tendência conservadora atribuída a todos os instintos orgânicos, não haveria outros que impulsionariam no sentido do progresso e da produção contínua de novas formas. Com efeito, tudo isso nada mais seria do que uma aparência enganadora, a qual esconde a real intenção de se livrar deles, por caminhos estratégicos, de maneira que o objetivo final de seu esforço seria não algo novo, mas originário, pretérito. Esse ponto de vista que evidentemente ecoa a tese de Schopenhauer, no Capítulo 27 de $O$ mundo como vontade e como representação, acerca do privilégio do primeiro ocupante. ${ }^{16}$

São essas as condiçóes que justificam seu argumento de que tudo o que vive morre por razóes internas (1920 e 1929). A consequência desse argumento foi o tornar-se mais uma vez inorgânico, o que entendemos como seu desdobramento. Argumento curioso, que nos impele a vincular morte interna e retorno ao inorgânico, pois, se a morte fosse uma fatalidade externa (uma aquisição tardia da vida, como pressupôs Weismann), os elementos de cada ser vivo abatido seriam incorporados ao abatedor. Queremos, com isso, dizer que, sendo exterior, a morte implicaria a circulação (a produção de fluxos) da substância orgânica e, portanto, a conservação da ordem biológica, evitando seu retorno ao inorgânico.

Talvez os argumentos de Lwoff nos ajudem a entender melhor essa questão. Para ele, um organismo vivo se autoconstitui, porque a substância hereditária é ao mesmo tempo o engenheiro e o mestre de obras de seu organismo, isto é, todo organismo metabolicamente sintetiza seus materiais de construção, como consequência de seu próprio funcionamento (LWOFF, 1969). Assim, produz trabalho e degrada energia, de sorte que toda ordem

\footnotetext{
${ }^{16}$ Trata-se, no entanto, de um uso particular do ponto de vista de Schopenhauer, como esclarece Fonseca (2016, p. 159): "Para o filósofo, o organismo (Organismus) é uma arena onde os diversos graus da exposição da Vontade se digladiam, e no final, a vitória -o domínio- é privilégio do primeiro ocupante: as forças do mundo inorgânico, sustentáculo e mantenedor do mundo orgânico. Mas, tudo isso de acordo apenas com o que se observa no curso da existência de um organismo individual, que é uma situação considerada inessencial. Do ponto de vista da Vontade como coisa-em-si, fora do tempo e do espaço, tal coisa não faz mais sentido, pois é exigida a perene concordância das partes entre si, do orgânico e do inorgânico numa determinaçáo recíproca." Seria o caso em que o crescimento e a complexificação da ordem biológica constituiriam, diferentemente do que admitiu Freud, resistência ao privilégio do primeiro ocupante, ao retorno ao inanimado.
} 
biológica, todo sistema vivo considerado em escala universal é dotado de um metabolismo "qui est corrélatif d’un accroissement d’entropie." (LWOFF, 1969, p. 175)..$^{17}$

Tudo isso só faz sentido, se pudermos identificar no pensamento de Freud um ponto de vista que julgamos de suma relevância, de que o homem e a civilização estariam em solução de continuidade com o mundo físico inorgânico. Só isso permitiria esclarecer as analogias que ele estabeleceu entre a natureza dos instintos, o funcionamento do aparelho psíquico e os sistemas físicos termodinâmicos. Esse ponto de vista adotado por Freud fica ainda mais evidente, se pensarmos, com Ritvo (1990), que foi o biólogo alemão Carl Claus, professor de Freud, quem lhe ensinou que a hipótese da seleção natural de Darwin rompeu definitivamente a dependência de doutrinas que até então fundamentavam e dominavam a biologia, forjando uma explicação físico-mecânica do desenvolvimento orgânico (inclusive dos instintos), por gradação e continuidade (em oposição à criação descontínua), a partir do inorgânico, por relaçôes (de forças) causais dos seres vivos com o meio ambiente, isto é, da síntese de compostos orgânicos (geleia primordial), com base em elementos inertes, inorgânicos.

Tal continuidade lhe permitiu considerar (apoiado em Darwin, em $A$ expressáo das emoçóes no homem e nos animais, 1872) que também os processos psíquicos e culturais teriam derivado do desenvolvimento do organismo, em vista das condiçôes ambientais, de uma trajetória evolutiva cuja aquisição esteve disposta numa linha de continuidade e coexistência entre processos físicos, biológicos e sociais. O próprio Freud (1920, p. 49) enfatizou:

Os instintos da vida foram, em determinada ocasião, evocados na matéria inanimada pela ação de uma força cuja natureza não podemos formar concepçáo. Pode ter sido um processo de tipo semelhante ao que posteriormente provocou o desenvolvimento da consciência num estado particular da matéria viva. A tensão que então surgiu no que até aí fora

\footnotetext{
${ }^{17}$ Seu argumento mais contundente, nessa obra, se deu em referência ao ponto de vista evolucionista. De acordo com Lwoff, o processo evolucionário foi efetivado por numerosos ensaios e "ils correspondent nécessairement à un accroisement d'entropie. L'organisation des systèmes vivants actuels a été acquise aux dépens d’une augmentation d'entropie." (LWOFF, 1969, p. 172). Apesar disso, ressaltou que, após um processo reprodutivo, os seres resultantes apresentam maior índice de entropia negativa, o que é positivo. Contudo, isso não permite afirmar que a entropia global tenha diminuído. Sua conclusão é que, de fato, "le système vivant considéré à une échelle universelle ne peut contredire le deuxième principe" (LWOFF, 1969, p. 173), ainda que a reprodução produza entropia negativa e proporcione ordem funcional ao organismo vivo, uma vez que a manutençấo e a reprodução da ordem biológica dependem de um mesmo processo, "le métabolisme, qui est corrélatif d’un accroissement d'entropie." (LWOFF, 1969, p. 175).
} 
uma substância inanimada se esforçou para neutralizar-se e, desta maneira, surgiu o primeiro instinto; o instinto de retornar ao estado inanimado.

É verdade que, nesse argumento, Freud não recorreu ao expediente kantiano de distinguir natureza de cultura, visando a possibilitar que o homem e a humanidade sejam pensados como obra de si mesmos. Todavia, trata-se de uma continuidade que não pressupóe que a cultura seja regida por leis naturais, mas certamente que está sujeita ao mesmo princípio geral. De fato, enquanto solidário do paralelismo psicofísico, Freud não tratou de explicar a vida biológica e psíquica, além da própria cultura, por meio de leis naturais. Entretanto, levou em conta que, pelo menos quando compreendido do ponto de vista econômica, o homem racional, em analogia com os sistemas físicos termodinâmicos, não é livre para fazer de si senão o que a natureza espera que faça, isto é, cumprir a finalidade de restituir sua condição inorgânica ou, como indicou Lwoff (1969), dissipar sua energia no ambiente, aumentando sua entropia positiva.

Nesses termos, compreendemos a metapsicologia de Freud (diferentemente de sua clínica e de suas técnicas de cura) como dotada da orientação finalista de recondução ao inorgânico, muito embora resultados diferenciados possam emergir em sua trajetória, os quais, devemos reconhecer, justificam a consideração de Monzani, de que o Princípio do prazer expressa, na verdade, "simultaneamente as tendências de Eros e de Tânatus." (2014, p. 217). Contudo, mesmo Eros opera nos domínios de Tânatus, uma vez que ambos operam segundo "a hipótese de que os processos vitais do indivíduo levam, por razóes internas, a uma abolição das tensões químicas, isto é, à morte”, reconheceu Freud (1920, p. 66). Isso, ao mesmo tempo em que asseverou que "a união com a substância viva de um indivíduo diferente aumenta essas tensôes, introduzindo o que pode ser descrito como novas 'diferenças vitais', que devem entâo ser vividas." (FREUD, 1920, p. 66).

Desse modo, parece evidente que resta a Eros, por seus próprios e diferentes caminhos, não contradizer nem destronar Tânatus, de sorte que o viver náo seja mais do que assumir o encargo de construir uma cultura, que não deve ser apreciada nem com pessimismo nem com otimismo, atendendo à máxima de seu reitor, o Princípio do prazer, o qual, segundo Freud (1920, p 74), "parece, na realidade, servir aos instintos de morte." É um princípio que orienta imperativamente a tendência de nos emancipar das excitaçôes, conduz toda forma de vida ao gélido repouso do inanimado, condução traçada filoge- 
neticamente na ocasião do "milagre" da emergência da vida, consequência do toque dos raios solares sobre a matéria inanimada.

BOCCA. F. V. The pleasure principle as a regulator of a civilization in decline. Trans/form/ ação, Marília, v. 42, n. 1, p. 123-152, Jan./Mar., 2019.

ABSTRACT: In this article, we reject the frequent pessimism regarding human life and the destiny of mankind that is found in Freud's work and often pointed out by his readers. This rejection is supported by the distinction in his work between metapsychology and clinical practice. Metapsychology, which is strongly related to the systematization of psychoanalysis, admits a naturalist determinism that on its own terms does not conceive the self-determination of man, civilization, or their destinies; that is, it does not have freedom as an operative notion. Metapsychology is marked by theoretical speculations composed of a certain evolutionary point of view shared with biology, and an entropic point of view taken from physics. We argue that metapsychology was thus conceived on the basis of principles that guide the evolution of man and humanity according to a purpose that entails their own exhaustion, and for that reason we call it entropic-declinist. The second domain, that of clinical practice, is related to diagnosis and healing techniques and sustains a notion of man and civilization that is not the result of natural or supernatural providence. It admits a kind of self-enlightenment, choice, and even self-regulation, aiming at human self-production and thus allowing a postponement of the entropic destiny of humanity; we call this emancipatory. Based on this distinction, we attempt to discern the philosophy of history and of nature contained in Freud's work.

KeYwords: Psychoanalysis. Clinic. Metapsychology. Evolution. Entropy.

\section{REFERÊNCIAS}

ACHA, O. Freud y el problema de la historia. Buenos Aires: Prometeo, 2007.

ASSOUN, P. L. Freud, a filosofia e os filósofos. Rio de Janeiro: Francisco Alves, 1978. . Introdução à epistemologia freudiana. Rio de Janeiro: Imago, 1983.

BOCCA, F. V. Do que depende a vida em sociedade? Trans/Form/Ação, Marília, v. 35, n. 3, p. 113-132, 2012.

Comte com Freud - possibilidades de pensar a história. In: FONSECA, E. R. et al. (org.). Pluralismo na psicanálise. Curitiba. Editora PUCPRESS, 2016. p. 29-55.

. Contribuição para o debate acerca de uso compartilhado em psicanálise. In: SIMANKE, R. T.; CAROPRESO, F.; BOCCA, F. V. (org.). Psicanálise em perspectiva VI. Curitiba: CRV, 2016. p. 289-309. 

7-28, 2017.

Freud e o programa científico kantiano. Revista Natureza Humana, v. 18, n. 2, p.

; MOUAMMAR, C. C. E. Civilizaçáo, sexualidade e entropia no pensamento de Freud. Revista de Filosofia Aurora. Curitiba, v. 23, n. 33, p. 441-452, 2011.

FONSECA, E. R. Psiquismo e vida: sobre a noção de Trieb nas obras de Freud, Schopenhauer e Nietzsche. Curitiba: Editora da UFPR, 2016.

FREUD, S. Moral sexual civilizada e doença nervosa moderna. Rio de Janeiro: Imago, 1969. Original publicado em 1908a. em 1908b.

. Escritores criativos e devaneios. Rio de Janeiro: Imago, 1969. Original publicado

. Formulaçôes sobre os dois princípios do funcionamento mental. Rio de Janeiro: Imago, 1969. Original publicado em 1911.

. Totem e tabu. Rio de Janeiro: Imago, 1999. Original publicado em 1913.

. Reflexóes para os tempos de guerra e morte. Rio de Janeiro: Imago, 1969. Original publicado em 1915. em 1920.

. Além do princípio do prazer. Rio de Janeiro: Imago, 1969. Original publicado

. Psicologia de grupo e a análise do ego. Rio de Janeiro: Imago, 1969. Original publicado em 1921.

. O problema econômico do masoquismo. Rio de Janeiro: Imago, 1969. Original publicado em 1924. em 1927.

. O futuro de uma ilusão. Rio de Janeiro: Imago, 1969, v. XXI. Original publicado . O mal-estar na civilização. Rio de Janeiro: Imago, 1997. Original publicado em 1929.

. Moisés e o monoteísmo. Rio de Janeiro: Imago, 1969. Original publicado em 1938.

FULGÊNCIO, L. O método especulativo em Freud. São Paulo: EDUC, 2008.

GABBI JUNIOR, O. F. Projeto de uma psicologia. Rio de Janeiro: Imago, 1995.

. Notas a projeto de uma psicologia. Rio de Janeiro: Imago, 2003.

JONES, E. La théorie du symbolisme. In: Traité théorique et pratique de psychanalyse. Paris: Payot, 1925. p. 206-277.

KANT, I. Crítica da razão pura. São Paulo: Abril Cultural, 1983. Original publicado em 1781.

- Idéia de uma história universal de um ponto de vista cosmopolita. São Paulo:

Brasiliense, 1986. Original publicado em 1784. 
BOCCA. F. V.

LOPARIC, Z. Objetificação e intolerância. Revista Natureza Humana, v. 9, n. 1, p. 51-95, 2007.

LWOFF, A. L'ordre biologique. Paris: R. Laffont, 1969

MONZANI, L. R. Freud: o movimento de um pensamento. Campinas: EDUNICAMP, 2014.

RITVO, L. B. A influência de Darwin sobre Freud. Rio de Janeiro: Imago, 1990.

SCHOPENHAUER, A. O mundo como vontade e como representação. Curitiba: Editora da UFPR, 2016. Tomo I.

Recebido: 04/12/2016

Aceito: 18/07/2018 